\title{
Challenging the Profiles of a Digital Library: A Survey on Empowering Creators to Increase Creativity Regarding an International Interdisciplinary Conference
}

\author{
Dwi Astuti Wahyu Nurhayati ${ }^{1 *}$
}

\author{
${ }^{1}$ State Islamic Institute of Tulungagung, Tulungagung, Indonesia \\ *Corresponding author.Email: dwiastuti507@gmail.com,dwiastuti@iain-tulungagung.ac.id
}

\begin{abstract}
This paper examines the EFL presenters' perception of viewing using digital library profiles on empowering creative presenters to an international conference. The data was collected for 4 months, starting from compiling three times surveys in October 2018 up to January 2019 in some conferences presenters. IAIN Tulungagung, UM, UNS, UI, and UNDIP campus in the sense of data collection, through the interview, and questionnaire. This study involves 30 Indonesian undergraduate students and 25 graduate students who were majoring in English, agriculture, literature, library, teaching language, Arabic and joint presentation in international interdisciplinary conferences. The presenter used and empowered the profiles of digital library in writing articles in some international conferences, held in some cities, namely East Java, Central Java, West Java, Indonesia. The data was analysed using a qualitative approach. The finding revealed that there were various presenters' perspectives in using the profiles of the digital library. The study also showed the benefits of using the digital library profiles such as online public access catalogue, links, feed display, category, E-resource; file E-book, LibX, Search box, management master file, web designer, proxy server, FTP server, mail server, database server and network administration. In addition, the profiles of the digital library encourage them to join the workshop of writing international article technique, know the ethic and strategy, fulfil the requirements of template paper, apply academic integrity, to be a member of research gate, and have ORCID ID. The results of this study proved that $76 \%$ of people give good feedback; most of them claimed that the digital library eases people into finding the desired book, saves time and effort; $28 \%$ felt challenged to be creative writers; while $54 \%$ chose to read literacy by digital library to add motivation to write or to be an author, writer or presenter.
\end{abstract}

\section{Keywords: Development, Learning Media, Macromedia Captivate}

\section{INTRODUCTION}

In this age of globalisation, technological development has a very large role in the world of education, especially in the field of libraries. The development of reading interest and reading habits is an achievement used to upgrade the virtue of human resources. The library is expected to be a place to develop reading interest and reading passion due to the role and function of the library as a centre for developing reading interest. This matter causes libraries to have a big responsibility, to gain many readers and compel them to read even more. Nowadays, libraries are not only in conventional form but also in digital form. Internet access is required to access the digital library when using that it can be easier and fast in providing information about the availability of books in a library. There are also benefits from the digital library. The saving room of the conventional library has limited and narrow places while the digital library acts as an economical place in which many books served in the digital form. As stated by Handoyo [1], the collections contained in the E-Library are in the form of digital, interactive, and libraries without a physical location. Meanwhile, in the academic field, universities can still use conventional libraries in the form of printed paper, but this can also make students become passive in cyberspace and require a long time to develop and adapt to the times [2].

Some researchers have conducted a study on digital libraries, paradigm, concept, and information technology. Kustandi and Situmorang [3] on their research about developing the digital library as learning sources proved that digital libraries as the place supply numbers of collection, services and are used to support conception, dissemination, utilisation, and data protection, as well as information, facts/news, and knowledge. This system has the disadvantage of not having centralised data properly causing difficulties in data search, so system improvements are needed by adding some features of the digital library to make it easier to search data as needed. In addition, it was found that this system has not been integrated with ICT so that it is still semi-digital. 
The emergence of this digital library has become a means for various layers of society to support their careers, especially for international presenters. The use of digital libraries is not an ordinary thing for presenters; therefore this, at the same time, becomes a challenge for them. A digital library provides internet facilities to help users to access data without the hindrance of distance and time. Mesiani [4] on the study explained that the good quality of human resources means that creativity and competence are needed to support the implementation of this system in order for the digital library to explore, manage and present the latest information to users. In other words, the context of increasing social capacity shows that digital libraries play an integral role as agents of change and social. As an agent of change, digital libraries identify various social impacts on community service, while as a social agent; digital libraries have a role and contribute to improving people's welfare through information literacy and technology programs. On the other hand, the existence of a digital library that is extensive cannot be used as a measurement to how widely it is used. As revealed by Mawere \& Sai [5] on their research about the use of e-resource among university students in a developing country, the existence of a digital library that is easily accessed is not always explored well. From the result of the study, it was found that there were minimum numbers of university students who utilize and use the digital library. So that the improvement of the media and the users must be created to increase their interest in using the digital library.

\section{LITERATURE REVIEW}

The library is a building that is used to store books and other works or a collection of group of collection books and /or other print or nonprint materials organized and maintain for use, it could be reading, consultation, study, and research. The library is an institution that manages materials in the form of books that are arranged systematically according to certain rules so that it can be used as a source of information by each user [6]. According to some experts, libraries are places, buildings, spaces, which are provided to maintain and use a collection of books, magazines and other library materials that are stored to be read, studied and discussed. Library from the Roman language is "librarium", which consists of the word "Liber" that means to book, while "Armarium" means cupboard [7]. So it can be concluded that the Library is a cupboard with books. Based on the definition above, it can be said that a library is a place in which data is followed according to a particular system that is used as a source of information for the users.

A digital library is a library that provides full-text data search services in full electronic format [1]. The digital library is an informal institution that provides sources of information stored in digital format, which can be accessed through networks, with the availability of staff with special expertise to select, compile, interpret, provide intellectual access, distribute, preserve and guarantee the existence of digital collections at all times that can be used by certain communities or selected communities, economically and easily [8]. A digital library operates as an information provider, service provider or user of information using networks and digital technology. However, the way in which the collection can be utilised, depends greatly on how the information is made, processed and presented.

In addition, the digital library is not only concerned with knowledge management and information, but it also explains that libraries as a source of information are expected to play a more role as a companion in the education process for a lifetime. Digital library services can facilitate the search for information in collections of information objects such as documents, images and databases in digital format quickly, precisely and accurately. In the formation of digital libraries, several key tools are needed, namely personal computers, internetworking and WWW (The World Wide Web). According to a better source, the digital library also requires information systems; it that there are three important elements needed in developing information systems, namely hardware, software and brainware [9]. The digital library also provides several menus that can be used by users to find information quickly and accurately such as: Ejournals, Repositories, catalogues and E-learning. There is no standard definition available for electronic journals. As a result, they are called by various names, such as scientific journals, virtual journals, paperless journals, online journals, scientific electronic journals, network journals, and journal CD-ROMs, which are electronically available for use with the help of computers and other communication technologies [10].

The collection of digital libraries is not limited to electronic documents substituting for printed forms; the scope of the collection reaches digital artefacts that cannot be replaced in printed form. Technological developments require libraries to provide sources of information in electronic form. The use of information in electronic form is now part of the modern lifestyle in society. This is used to reconcile the bidding of the number and essence of library services, resource sharing, the effectiveness of human resources, time efficiency and the diversity of information managed. Lihitkar \& Lihitkar [11] on their study about open source software for developing digital library stated that the services of digital libraries have centred on information and highbrowed technology because it can be accessed from remote places. While according to Khumar [12], the digital library serves to increase the connection, as well as it can include cost saving, preservation, keeping peace with hi-tech and knowledge sharing.

In addition, Khumar [12] mentioned that the benefits of a digital library include preserving rare and fragile objects by enhancing their access to multiple referencing, wide area usage, archival storage and security measure. Stand-alone Digital Library, Federated Digital Library and Harvested Digital Library are the kinds of existing digital libraries today. Based on the American Digital Library Federation, digital libraries are citations that preserve the resources; they are specialised staff, who select, structure, offer intellectual access to, interpret, distribute and ensure the 
persistence of a collection of digital works over time so that they are readily and economically suitable for use by the communities. He presented that the digital library has a diverse network that can be accessed anytime in every place.

\section{RESEARCH METHOD}

This research uses the descriptive qualitative method, in which data were collected through questionnaires and interviews. The balance of 'an acquaintance of achievability', utilisation, the aim of the appliance, discovered profit and difficulties are a concurrence in their employment of e-courses. The sampling has both closedand open-ended questions. The sampling of this study were entranced by conferring the sampling to some conference presenters of IAIN Tulungagung, UM, UNS, UI, and UNDIP. According to some experts, the data analysis technique used for evaluating expert reviews is calculating the questionnaire value based on a predetermined rating scale. The information provided was held to make the validity of the data. The total is 30 Indonesian undergraduate and 25 graduate students who are majoring in English, agriculture, literature, library, teaching language, Arabic and joined presentation in international interdisciplinary conferences. The presenter used and empowered the profiles of digital libraries in East Java, Central Java and West Java, Indonesia. The data in this article were collected for 4 months, starting from the compiling survey in October 2018 to January 2019 in some conferences presenters of IAIN Tulungagung, UM, UNS, UI, and UNDP.

\section{RESULT}

The data of Indonesian presenters' perspectives on using digital library software was defined as a tendency to browse, flip through, operate, utilise, adapt and employ the facilities provided in the networked library in order to support them to become creative writers. From the analysis, the first research objective was met, that is, the perceptions that enhance their knowledge and competence in using accessible library: (i) the perception of using digital library (ii) the role of digital library towards writing an article or others (iii) the role of Digital Library towards being an author, or writer or presenter, and (iv) the advantages of digital library.

\subsection{The Perception of Using Digital Library}

Fig 1. The Percentage Of People Perception Using Digital Library

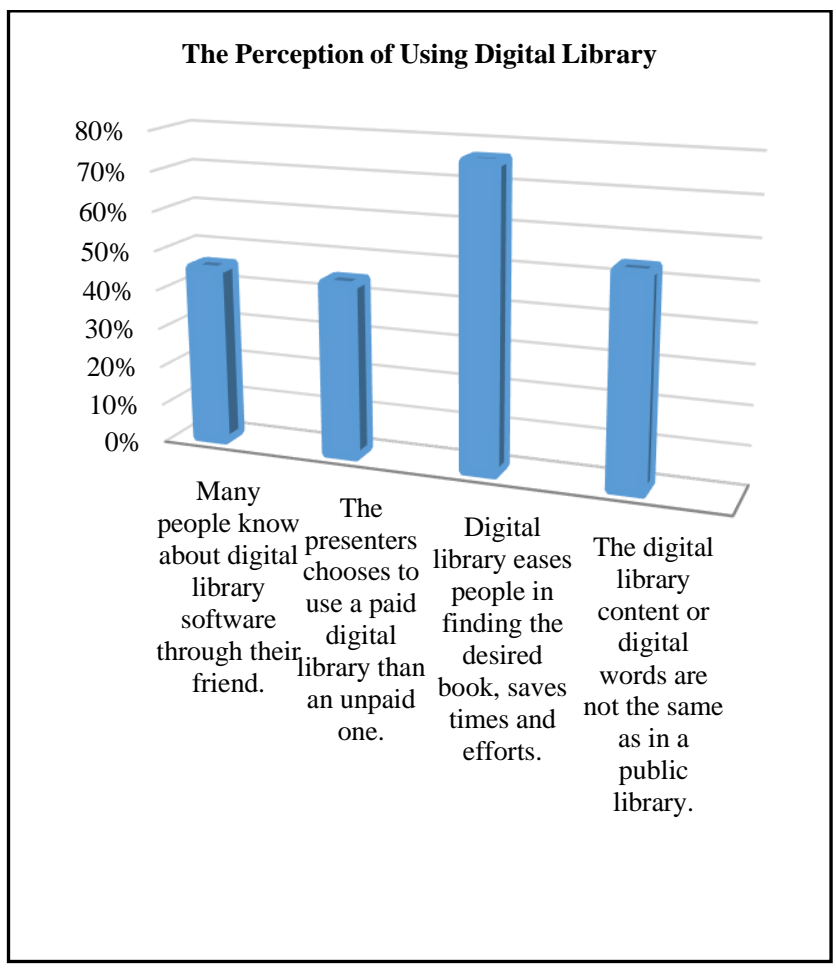

The figure above displayed that $45 \%$ of people know about digital library software through their friend. Then, $44 \%$ of the presenters choose to use a paid digital library than an unpaid one. $76 \%$ of people feel that using digital library eases them in finding the desired books, as well as saves times and efforts, while $53 \%$ of people know that the digital library. The digital library content or digital words are not the same as in a public library. 


\subsection{The Role of Digital Library towards Writing an Article or Others}

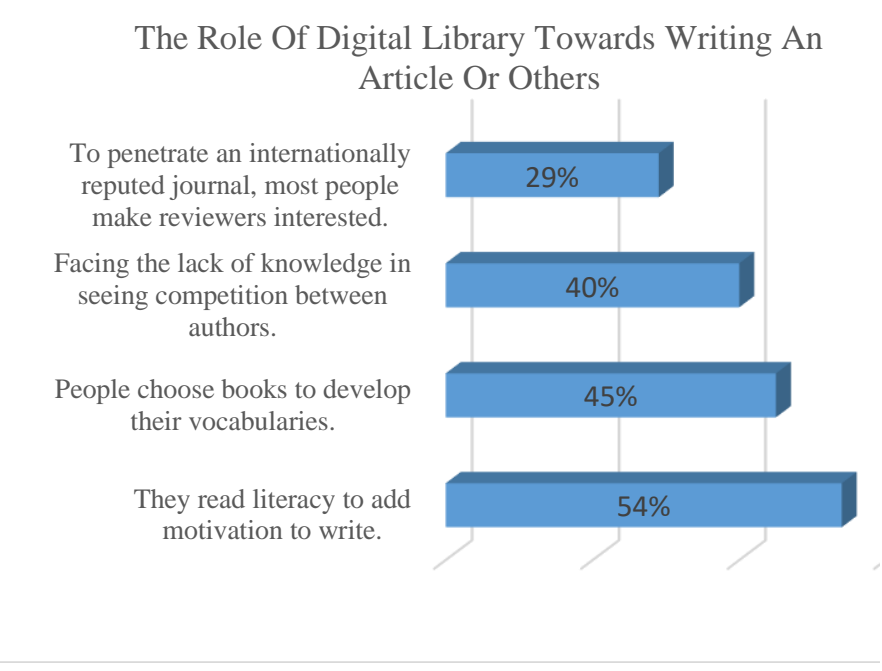

Fig 2. The Percentage Of The Digital Library Role Towards Writing An Article Or Others

The figure displayed the role of the digital library towards writing an article or others. $54 \%$ of people read literacy to add motivation to write, and $45 \%$ of them choose books to develop their vocabularies. Then, $40 \%$ of people face the lack of knowledge in seeing competition between authors. Also, to penetrate an internationally reputed journal, 29\% people make reviewers interested.

\subsection{The role of Digital Library towards being an author, writer or presenter}

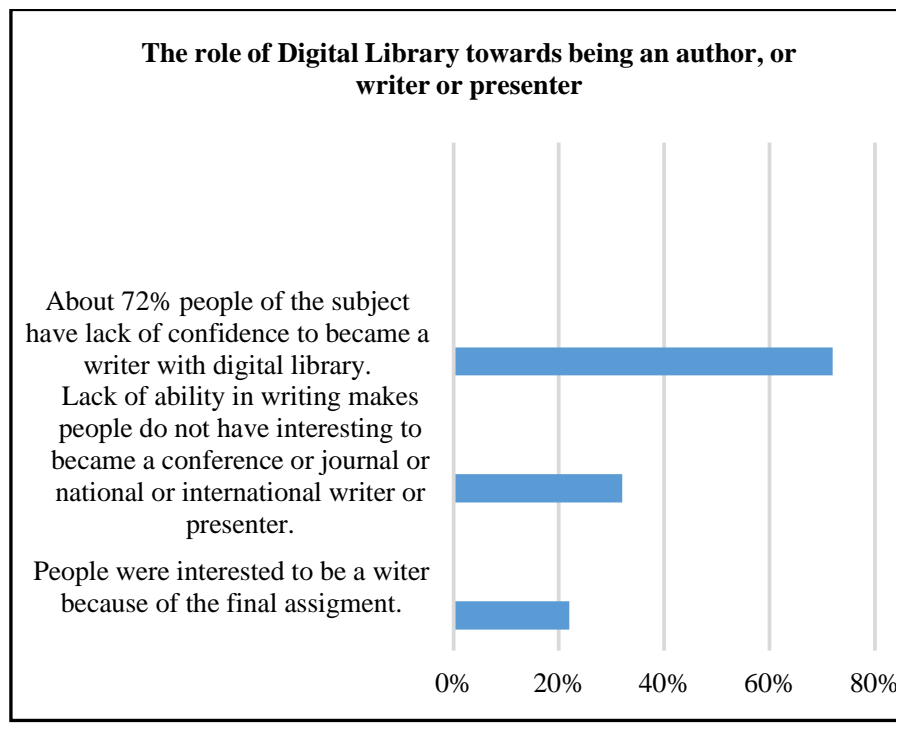

Fig 3. The Percentage Of Digital Library Role Towards Being An Author, Or Writer Or Presenter

The figure revealed that $22 \%$ of people were interested in being a writer because of the final assignment. Then $32 \%$ of people had no interest in becoming a conference writer or presenter because of the lack of writing ability. Further, $72 \%$ of people of the subject lack the confidence to become a writer with a digital library.

\subsection{The Advantages of Digital Library}

The finding also shows that the respondents had some perception about the benefits of using the digital library. In particular, the perception or ideas on using digital library was taken by conducting some activities, which can be seen in the figure below.

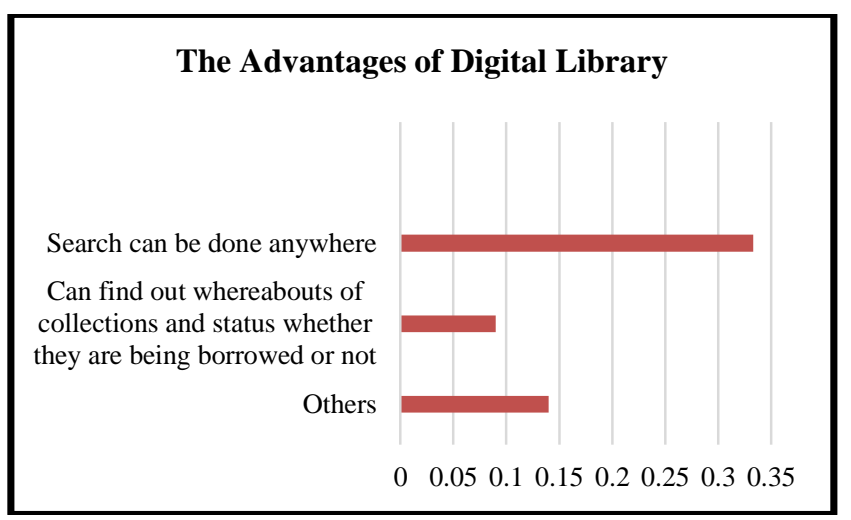

Fig 4. The Percentage Of The Advantages

The figure presents that the highest percentages of people $(59 \%)$ claimed that the main advantage of using a digital library is that it can be done anywhere as long as they connected to the internet. About $16 \%$ of the people said that it can find out the whereabouts of collections and status whether they are being borrowed or not. $25 \%$ of responders have another opinion about it.

\section{DISCUSSION}

From all the findings above, there are some perspectives of presenters about the digital library based on the questionnaires such as the different opinions of presenters about software digital library Lihitkar \& Lihitkar [11] on their study, they mentioned that open source software (OSS) has different complementary, goals and strengths. Besides, there are some different reasons why the presenters were interested in being a writer, because of the final assignment, the motivation that comes from academic writers, the challenge to compete with the writers, just a fad and add revenue.

The result showed that most of the presenters use the paid version of the digital library than unpaid. It is happening because the quality of the network was better; it also could guarantee to find out the books they look for. The digital library gives more advantages than an unpaid digital library for the presenters. In other words, using digital library made it easier for the presenters to find a specific book. However, the paid digital library was a problem when the network was down.

There are some people who do not have the interest to become a conference/ journal/ national/ international writer/ 
presenter for the following reasons: they prefer reading than writing because they assumed that writing is more difficult. Indirectly, this situation can decline, depreciate, and diminish the confidence of people to express their idea. In addition, people think that they have a lack of writing ability due to doubt with creativity. The confidence of people differed. The digital library has some advantages such as it can be accessed anywhere as long as one is connected to the internet; people can find out the whereabouts of collections and status whether they are being borrowed or not, and others opinion about it. According to someone experienced in the field, traditional libraries have limitations relating to the arcade and route of data, as a result of the greatest of comprehension of the library users is shared and provided by libraries documented and composed intangible media. Virtual libraries are similar to traditional libraries; both cover a large collection of information and in terms of common ones, give an account of arranging, fetching, accessing, storing, extracting and sustentation of information. The digital libraries concept refers to libraries that use information technology to improve their ability to feel and respond to their environment substantially.

According to Nurachman [14], data is necessary for a call creating; therefore it shouldn't be too late. For example, if information from an associate degree is late received by the data users then it will bring some disadvantages because it is hoped that the data came simply in time or punctual. By processing computer-based library information in accounting data systems, the matter of speed in manufacturing data may be resolved. The computer has tested the speed of the method. Accurate implies that the data created is exactly in accordance with the aim of information process. Associate degree information should be correct considering that the method of running information from the data supply to the recipient, encompasses a lot of noise or disturbances, which will change or harm the information. Librarians have time and energy limits; however, this is not the case with computerbased systems. People also face difficulties when writing, as due to the lack of knowledge in seeing competition between authors, the people feel inferior in comparison to the writings that have been read in the digital library; people claimed that sometimes writing feels heavier than reading. The digital library presents the software in a simple form where the people can easily access the information quickly, easily find the desired book and save time and effort. This research is also supported by another researcher that conducted the study entitled A Reflection of Tanzanian Libraries in the Digital Age: Challenges and Prospects Muneja, P. S., [13]. The facilities that are equipped with digital libraries with the internet network can make it easier for users to access information without obstacles such as distance and time.

To face the challenge in writing, people add books typically to develop the vocabulary, see the competitive aspect; take note and to be senior writers. The result showed that a lot of individuals fathom code digital library through their friend or social media, by attending coaching or workshops and conjointly obtained from a Google computer program. Creating a digital library is easier to contend with in the world of writing as an ingenious author. There are some tips for writing an internationally acknowledged journal in pursuing an associate degree; the people knowing the market share of the reader, will build the best optimal journal manuscripts with proper content and presentation. The majority users of profiles of a digital library confess that it builds their interests in reviewing papers, therefore, they avoid plagiarism.

\section{CONCLUSION}

To my knowledge, prior to this study, only a few types of research attempted to explore the EFL presenters' perception using the profiles of the digital library. This empowers creative presenters to partake in an international conference, more specifically Indonesian English-writers who are under-represented in using digital library research. Most previous researches examined the effect of digital library and users' experience while using a digital library to economically and effectively supply quality service. Further, users have a positive perspective towards the digital library, however most times; most of them are unaware of the varied services offered by the digital library. It is also found that the interface is a vital issue when using the digital library. It is known that some EFL presenters' perception differs when using the profiles of the digital library on empowering creative presenters to a global conference. The digital library was developed and spreads quickly via word of mouth, training or workshops, social media; utmost people choose to use the paid version of the digital library than the unpaid. The majority of presenters claimed that digital library provides a massive influence on their literacy. The digital library has several benefits; however, the main one is that it is accessible everywhere and anytime. The digital library makes it easier to contend with the world of writing as an explicit author. Some people have the interest to become a conference/journal/national/international writer/presenter; however, others also admit that it practice their academic integrity or academic writing skill.

\section{REFERENCES}

[1] Handoyo, Eko (2012). "Layanan Perpustakaan". Universitas Negeri Semarang. Retrieved from https://www.academia.edu/531991

[2] brahim, Ali \& Afrina Mira. 2011. Pengembangan Model Perpustakaan Berbasis Teknologi Informasi Untuk Meningkatkan Kinerja Layanan Perpustakaan dan mewujudkan perpustakaan ideal berbasis digital di Fasilkom Unsri. Khusus Dalam Globalisasi Informasi: Retaining The Presence of Special Library in Information Globalization. J. Pari Vol. 1 No. 1, pages: 37-43.

[3] Kustandi, Cecep, \& Situmorang, Robinson. 2013. Pengembangan Digital Library Sebagai Sumber Belajar. Perspektif Ilmu Pendidikan, 27 (16).

[4] Mesiani, Ketut. 2015. Mempertahankan Keberadaan Perpustakaan Pada Fakultas Teknologi Industri UPN 
"Veteran" Yogyakarta. Telematika, Vol. 9, No. 2, January 2013: 109 - 116.

[5] Mawere, T. \& Sai, K.O.S., 2018, 'An investigation on e-resource utilization among university students in a developing country: A case of Great Zimbabwe University', South African Journal of Information Management 20(1), a860. Retrieved from https://doi.org/ 10.4102/sajim.v20i1.860.

[6] Kumah, Cynthia H. (2015). A Comparative Study of the use of the Library and the Internet as Sources of Information by Graduate Students in the University Of Ghana. Library Philosophy and Practice (e-journal). Retrieved $23 \quad$ February 2019 from https://digitalcommons.unl.edu/cgi/viewcontent.cgi?a rticle $=3473 \&$ context $=$ libphilprac,

[7] Readers and Their Books. (2018). In E. Kwakkel \& R. Thomson (Eds.), The European Book in the Twelfth Century (Cambridge Studies in Medieval Literature, pp. 85-156). Cambridge: Cambridge University Press.

[8] Trivedi, Mayank, "Digital Libraries: Functionality, Usability, and Accessibility" (2010). Library Philosophy and Practice (e-journal). 381, accessed 23 $\begin{array}{lll}\text { February } & 2019 & \text { from }\end{array}$ http://digitalcommons.unl.edu/libphilprac/381.

[9] Wulandari, Aminin S., Dacholfany, M.I., Mujib, A., Huda, M., Nasir, B.M., Maseleno, A., Sundari, E., Fauzi, Masrur, M. (2018). Design of a library application system. International Journal of Engineering \& Technology, 7 (2.27), 199-204.

[10] Ashikuzzaman, Md. About Electronic Journal (EJournal). Library and Information Science Network.
February 7, 2018. Accessed 23 February 2019 from http://www.lisbdnet.com/electronic-journal-e-journal/

[11] Lihitkar, S. R. \& Lihitkar, R. R. (2012). Open Source Software for Developing Digital Library: Comparative Study. DESIDOC Journal of Library \& Information Technology, 32(5), 393-400. Nagpur University.

[12] Khumar, Mishra R. (2016). Digital Libraries: Definitions, Issues, and Challenges. Innovare Journal of Education. Vol. 2, Issue. 3. Retrieved 23 February 2019 from https://www.google.com/url?sa=t\&source=web\&rct= j\&url=https:///innovareacademics.in/journals/indexs

[13] Muneja, P. S., 2010. A Reflection of Tanzanian Libraries in Digital Age: Challenges and Prospects. Mbeya Tanzania: University of Dar es Salaam. https://www.google.com/url?sa=t\&source=web\&rct= j\&url=https://www.researchgate.net/profile/Paul_Mu neja/publication/258831780_A_Reflection_of_Tanza nian_Libraries in the Digital_Age Challenges and _Prospects/links/00463529076c895b9a000000/AReflection-of-Tanzanian-Libraries-in-the-DigitalAge-Challenges-and-

Prospects.pdf\&ved=2ahUKEwjE-JR5ffjAhXjjuYKHbh7D1EQFjAAegQIAxAB\&usg= AOvVaw16GHjSPlMgNkQWc1nii1Y5

[14] Nurachman, S., 2004. Perpustakaan sebagai Jembatan Pengetahuan, Seminar Nasional Jaringan Dokumentasi dan Informasi di Era Informasi/Masyarakat Berpengetahuan 2004. Ubaya Library: Surabaya. 